\title{
Long-term changes in snow cover depth in eastern Europe
}

\author{
Ewa Bednorz ${ }^{1, *}$, Tomasz Kossowski ${ }^{2}$ \\ ${ }^{1}$ Institute of Physical Geography and Environmental Planning, and ${ }^{2}$ Institute of Socio-Economic Geography and \\ Spatial Management, Adam Mickiewicz University, ul. Fredry 10, 61-701 Poznań, Poland
}

\begin{abstract}
We investigated changes in snow cover depth in eastern Europe over a period of about $100 \mathrm{yr}$, analyzing data for 5 stations located on the territory of the former Soviet Union. First we determined the basic characteristics of snow cover occurrence at each station: mean and extreme values of snow cover depth, standard deviation and variability index. Then, trends of changes in the mean monthly snow cover depth were analysed and turning points were identified using a Mann-Kendall test. Snow cover depth has decreased significantly at the 3 easternmost stations (Orenburg, Kirov, Gorkij), but at Kirov snow cover depth has increased again since 1950. At Vilnjus snow cover depth has decreased rapidly since the early 1980s.
\end{abstract}

KEY WORDS: Eastern Europe - Trend analysis · Snow cover Resale or republication not permitted without written consent of the publisher

\section{INTRODUCTION}

Winter snow cover is an important climatic variable at temperate latitudes. It is determined by air temperature, precipitation, and indirectly by atmospheric circulation. On the other hand snow cover modifies surface albedo, which is very important for the earth-atmosphere energy budget (Robock 1980, Robinson \& Kukla 1985), thus having a strong impact on the climate system. It modifies the weather conditions mainly by lowering the air temperature (Wagner 1973, Dewey 1977, Walsh et al. 1982), and by changing air circulation, cloud cover and precipitation (Johnson et al. 1984, Namias 1985, Cohen 2001).

There are a number of studies on the temporal variability in snow cover at different spatial scales. Global scale studies are based on weekly digitized maps of northern hemisphere snow cover available since 1972 (Gutzler \& Rosen 1992, Groisman et al. 1994). Longterm northern hemisphere snow cover variability and change have been studied by Brown (2000) on the basis of historical and reconstructed data. Continental scale research of the recent variations in snow cover in relation to precipitation and temperature was carried out for North America by Karl et al. (1993). Long-term studies on snow cover variability have been conducted in Canada and the USA (Brown \& Goodison 1996, Hughes \& Robinson 1996). There are also some papers by European authors describing snow cover temporal variability on a local scale (Jaagus 1997, Bednorz 2002, Falarz 2002).

Ye et al. (1998) and Ye (2000) studied snow cover changes in the former Soviet Union over the period of 1936-1983. They found different patterns of snow depth variation in Russia: snow accumulation decreased in the SE sector of European Russia, but it increased in the major part of the country, especially at higher latitudes in Siberia.

The aim of our study was to detect changes in snow cover depth in eastern Europe over the past $100 \mathrm{yr}$, using 5 stations from the territory of the former Soviet Union with an adequate dataset. Trends of changes in snow cover depth were investigated, and the approximate times of turning points were identified.

\section{DATA AND METHODS}

This study was based on daily snow cover depth data obtained from Historical Soviet Daily Snow Depth 


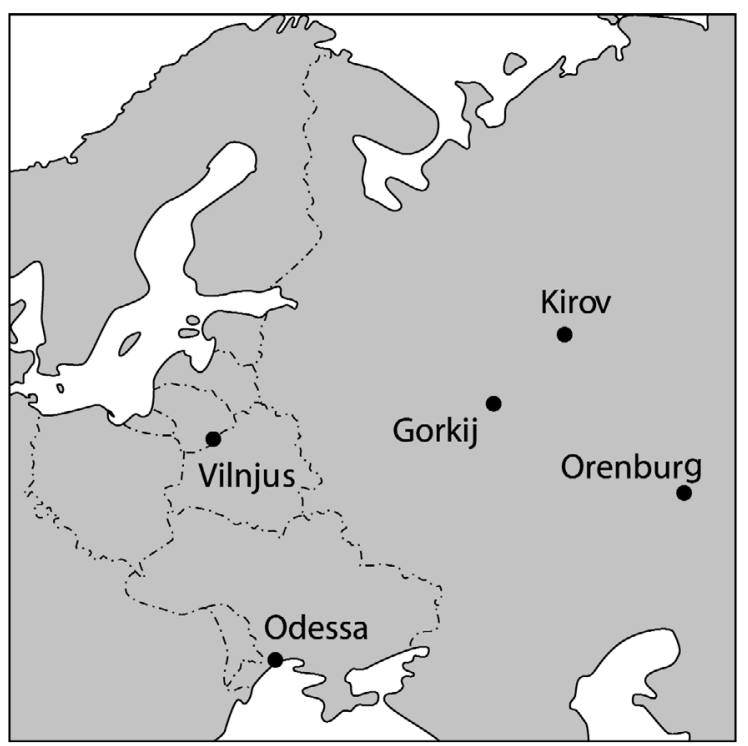

Fig. 1. Weather stations with 100 yr snow cover data

(HSDSD) Version 2 (Armstrong 2001). The snow depth data are based on daily measurements from 3 snow measuring rods, i.e. they are the average of 3 readings (in $\mathrm{cm}$ ). HSDSD contains data based on observations from the 284 World Meteorological Organisation stations which operated in the former Soviet Union territory during 1881-1995. However, most of the stations have records covering much shorter periods. HSDSD Version 2 was quality controlled by the National Snow and Ice Data Center, Boulder, Colorado. The procedures followed in checking the homogeneity of the database are described in Robinson (1993; HSDSD Version 1) and Armstrong (2001; HSDSD Version 2).

We chose those 5 stations from the European part of the former Soviet Union with the longest data records for this study (Fig. 1; station names follow the HSDSD data source, but the present Russian names of some stations are given in brackets in Table 1). Table 1 shows the data records available for each station and the years with missing values; there are additional gaps at most of these stations during the Second World War (1941-1945). It was not possible to use the ratio test (Alexanderson 1986) for gap filling, as there were no nearby stations conducting meteorological observations during these years. Some simulations were made, substituting mean, minimum or maximum values for gaps. Finally, we replaced gaps with mean values of winter snow cover depth.

Kirov, located farthest to the northeast, has the longest average duartion of snow cover $\left(175 \mathrm{~d} \mathrm{yr}^{-1}\right)$, followed by Gorkij (155 $\left.\mathrm{d} \mathrm{yr}^{-1}\right)$ and Vilnjus (100 d $\left.\mathrm{yr}^{-1}\right)$. The shortest period of snow cover $\left(<50 \mathrm{~d} \mathrm{yr}^{-1}\right)$ is in Odessa on the Black Sea coast (Bednorz 2004).

Mean monthly and winter depths of snow cover provided the basis for analysis of snow cover changes. Mean monthly snow depths were calculated by averaging daily values for each month. Mean winter snow depths were averages for November-April (Kirov, Gorkij, Orenburg) or for December-March (Vilnjus and Odessa). Missing days were omitted from the calculation, i.e. we did not use estimates for missing data. We first determined the basic characteristics of snow depth at each station and identified average maximum and minimum values of snow depth per month. To investigate extreme values, we determined the absolute daily maximum for each month. Finally, the standard deviation (SD) and variability index (quotient of SD and arithmetic mean, in \%) were calculated for each month.

Next, linear trend equations were constructed for each month and for each winter. Snow cover depth changes over $100 \mathrm{yr}$ were calculated on the basis of linear trend equations.

To detect changes in the trends of mean winter snow depth during the study period the sequential form of the non-parametric Mann-Kendall test was applied. The test enables recognition of rapid changes of the variable analysed from higher to lower values or vice versa, also detecting changes in the direction of the trend (see Sneyers 1990, cited in Brunetti et al. 2001). The test has been used for climatic purposes, for instance to investigate the precipitation trends in NE Italy (Brunetti et al. 2001) and to determine atmospheric circulation periods (Wibig 2001).

The null hypothesis of the absence of any trend was verified by the non-parametric Mann-Kendall test. The test statistics are given by:

$$
t=\sum_{i} n_{i},
$$

where $n_{i}$ is the number of elements $x_{j}$ of the series which meet the condition $x_{j}<x_{i}$ and $j=1, \ldots, i-1$ for each $x_{i}, i=2, \ldots, n_{\text {r. }}$.

Table 1. Location of the stations, and available snow cover data period; $\mathrm{m}$ asl: meters above sea level

\begin{tabular}{|lccccc|}
\hline & $\begin{array}{c}\text { Lat. } \\
\left({ }^{\circ} \mathrm{N}\right)\end{array}$ & $\begin{array}{c}\text { Long. } \\
\left({ }^{\circ} \mathrm{E}\right)\end{array}$ & $\begin{array}{c}\text { Elevation } \\
(\mathrm{m} \text { asl })\end{array}$ & $\begin{array}{c}\text { Data period } \\
(\mathrm{yr})\end{array}$ & $\begin{array}{c}\text { Missing } \\
\text { data (yr) }\end{array}$ \\
\hline Kirov (Vyatka) & 58.5 & 049.7 & 164 & $1921-1995$ & $1936-1939$ \\
$\begin{array}{l}\text { Gorkij (Nizhny } \\
\text { Novgorod) }\end{array}$ & 56.3 & 044.0 & 82 & $1897-1995$ & $1919-1922$ \\
Orenburg & 51.8 & 055.1 & 109 & $1900-1995$ & $1957-1961$ \\
Vilnjus (Vilnius) & 54.7 & 025.3 & 189 & $1901-1993$ & $1914-1917$ \\
Odessa & 46.5 & 030.6 & 64 & $1894-1992$ & \\
\hline
\end{tabular}


Provided that the null hypothesis is correct, the statistics

$$
u(t)=[t-E(t)] / \operatorname{var}^{2}(t)
$$

have a normal distribution, with an expected value $E(t)$ and variance $\operatorname{var}^{2}(t)$ expressed by, respectively:

$$
\begin{gathered}
E(t)=n(n-1) / 4 \\
\operatorname{Var}^{2}(t)=n(n-1)(2 n+5) / 72
\end{gathered}
$$

The null hypothesis is rejected at the significance level A, when

$$
\mathrm{p}\left(\left|z_{\alpha / 2}\right|<|u(t)|\right)=\alpha
$$

where $z_{\alpha / 2}$ is a quantile order $\alpha / 2$ of the normal distribution.

The sequential form of the Mann-Kendall test enables determination of the approximate moment when significant changes in the trend occur. The null hypothesis of no significant change in the trend in $x_{i}$ can therefore be rejected at $\alpha$ when $u\left(t_{i}\right)>v\left(t_{i}\right)$ and $u\left(t_{i+1}\right)<v\left(t_{i+1}\right)$ or $u\left(t_{i}\right)<v\left(t_{i}\right)$ and $u\left(t_{i+1}\right)>v\left(t_{i+1}\right)$, while at least one of the values $u\left(t_{i}\right), u\left(t_{i+1}\right), v\left(t_{i}\right), v\left(t_{i+1}\right)$ fulfils the condition of Eq. (5) (see Gerstengarbe \& Werner 1999). Values of $v(t)$ for the backward series beginning at $i$ and ending at the $n$th observation are calculated on the basis of Eq. (2), replacing $u(t)$ by $v(t)$.

\section{RESULTS}

The main snow cover characteristics of the stations are given in Table 2. At Kirov, which has the greatest quantity of snow, the mean monthly snow cover depth (averaged for the whole studied period) increases from October to March and then quickly decreases. At the other stations, the largest values occur in February and March. At Odessa, which has the lowest quantity of snow cover, the maximum usually occurs in January and February. The first and the last months of winter are characterised by great diversity in the mean snow cover depth, i.e. the beginning and the end of the period of permanent snow cover vary from year to year and the difference may exceed $30 \mathrm{~d}$. At Odessa, where permanent snow cover does not form at all, the variability index exceeds $150 \%$ in January, February and March and it exceeds $200 \%$ in November and December.

The daily and monthly mean maximum snow cover depths at Kirov and Gorkij were extremely high at the beginning of the 20th century. At Kirov, daily snow cover depth attained $182 \mathrm{~cm}$ and the mean value for March 1902 was $143.5 \mathrm{~cm}$ in 1901/1902 and 1904/1905. At Gorkij the maximum was $113 \mathrm{~cm}$ and the March monthly mean $>100 \mathrm{~cm}$ in 1902. At Vilnjus, extreme snow cover values occurred at the beginning of the 1960s and 1980s, with the maximum in December, January and February 1981/1982 $(51.4 \mathrm{~cm})$; the daily extreme was $56 \mathrm{~cm}$ in March 1965.

Equations of the linear trends of changes in the mean monthly and annual snow cover depth were developed for each station (Table 3). The maximum decreases in mean monthly snow depth over the $100 \mathrm{yr}$ period were found at Orenburg $(>30 \mathrm{~cm}$ in March, $>20 \mathrm{~cm}$ in January and February). At Gorkij snow cover depth decreased by $>10 \mathrm{~cm}$ in January and February, and almost $20 \mathrm{~cm}$ in March and April. At Kirov, a statisti-

\begin{tabular}{|c|c|c|c|c|c|}
\hline & \multicolumn{3}{|c|}{$\begin{array}{l}\text { Monthly snow cover } \\
\text { depth }\end{array}$} & \multicolumn{2}{|c|}{$\begin{array}{l}\text { Maximum snow cover } \\
\text { depth }\end{array}$} \\
\hline & Mean & $\mathrm{SD}$ & $\begin{array}{l}\text { Variabi- } \\
\text { lity }(\%)\end{array}$ & $\begin{array}{l}\text { Monthly } \\
\text { mean }\end{array}$ & Day \\
\hline \multicolumn{6}{|c|}{ Kirov } \\
\hline Oct & 1.2 & 1.7 & 139 & 6.6 (1973) & 24 (1925) \\
\hline Nov & 8.5 & 5.8 & 68 & 26.9 (1910) & 49 (1904) \\
\hline Dec & 24.0 & 11.5 & 48 & 60.5 (1904) & 70 (1904) \\
\hline Jan & 40.5 & 13.8 & 34 & 76.5 (1905) & 83 (1905) \\
\hline Feb & 51.9 & 15.6 & 30 & $92.6(1902)$ & 175 (1902) \\
\hline Mar & 55.6 & 19.1 & 34 & $143.5(1902)$ & 182 (1902) \\
\hline Apr & 17.5 & 15.3 & 87 & $67.4(1923)$ & 93 (1914) \\
\hline \multicolumn{6}{|c|}{ Gorkij } \\
\hline Oct & 0.7 & 1.2 & 169 & 7.9 (1903) & 26 (1971) \\
\hline Nov & 5.2 & 4.1 & 80 & 18.5 (1956) & 40 (1914) \\
\hline Dec & 18.5 & 10.2 & 55 & 55.9 (1907) & 83 (1907) \\
\hline Jan & 34.3 & 13.1 & 38 & 80.6 (1908) & 89 (1908) \\
\hline Feb & 47.3 & 14.6 & 31 & 94.5 (1908) & 102 (1908) \\
\hline Mar & 47.0 & 16.4 & 35 & $101.7(1902)$ & 113 (1902) \\
\hline Apr & 10.5 & 11.4 & 108 & 48.5 (1923) & 88 (1994) \\
\hline \multicolumn{6}{|c|}{ Orenburg } \\
\hline Oct & 0.2 & 0.5 & 201 & 2.3 (1969) & 21 (1945) \\
\hline Nov & 3.5 & 4.5 & 130 & 27.7 (1906) & 36 (1906) \\
\hline Dec & 12.7 & 10.2 & 81 & 63.0 (1933) & 108 (1933) \\
\hline Jan & 23.9 & 15.3 & 64 & 94.3 (1934) & 99 (1934) \\
\hline Feb & 31.8 & 17.8 & 56 & $100.6(1934)$ & 114 (1934) \\
\hline Mar & 31.5 & 21.1 & 67 & 118.9 (1934) & 136 (1934) \\
\hline Apr & 5.5 & 9.2 & 167 & 48.5 (1934) & 116 (1934) \\
\hline \multicolumn{6}{|c|}{ Vilnjus } \\
\hline Oct & 0.0 & 0.1 & & 0.6 (1992) & 7 (1925) \\
\hline Nov & 0.9 & 1.3 & 146 & 6.4 (1909) & 24 (1950) \\
\hline Dec & 4.9 & 4.6 & 94 & 30.6 (1981) & 39 (1981) \\
\hline Jan & 10.4 & 8.5 & 82 & 43.4 (1982) & 50 (1982) \\
\hline Feb & 14.8 & 12.0 & 81 & $51.4(1982)$ & 55 (1960) \\
\hline Mar & 10.5 & 10.1 & 97 & 40.4 (1980) & 56 (1965) \\
\hline Apr & 0.4 & 1.0 & & 4.5 (1958) & 25 (1941) \\
\hline \multicolumn{6}{|c|}{ Odessa } \\
\hline \multicolumn{6}{|c|}{ Oct } \\
\hline Nov & 0.0 & 0.1 & 270 & $0.3(1965)$ & 4 (1924) \\
\hline Dec & 0.5 & 1.1 & 209 & $8.7(1902)$ & 16 (1902) \\
\hline Jan & 1.7 & 2.5 & 148 & $13.7(1954)$ & 33 (1937) \\
\hline Feb & 1.7 & 2.7 & 162 & $16.4(1937)$ & 28 (1901) \\
\hline Mar & 0.5 & 1.0 & 184 & $4.9(1932)$ & 19 (1901) \\
\hline Apr & & & & & $1(1918,1995)$ \\
\hline
\end{tabular}

Table 2. Characteristics of snow cover depth (cm) for the winter months at 5 eastern European stations. Variability $=\mathrm{SD} /$ mean; data in brackets are year of occurrence 
Table 3. Changes in snow cover depth (cm per decade) during the data periods, computed from linear trend equations in Fig. 3. Statistically significant values in bold $(\mathrm{p}<0.01)$ or normal font $(\mathrm{p}<0.05)$; not significant values $(\mathrm{p} \geq 0.05)$ in italics

\begin{tabular}{|lrrrrrrrr|}
\hline & Oct & Nov & Dec & Jan & Feb & Mar & Apr & Mean \\
\hline Kirov & 1.34 & -1.33 & -7.49 & -8.34 & -12.52 & $\mathbf{- 2 5 . 2 3}$ & $\mathbf{- 2 5 . 6 1}$ & $\mathbf{- 1 5 . 0 8}$ \\
Gorkij & -0.15 & 1.41 & -7.65 & -11.37 & -12.32 & $\mathbf{- 1 7 . 7 1}$ & $\mathbf{- 1 8 . 3 9}$ & -11.37 \\
Orenburg & 0.12 & -2.26 & -9.43 & $-\mathbf{2 3 . 4 4}$ & $\mathbf{- 2 6 . 8 1}$ & $\mathbf{- 3 5 . 4 6}$ & $\mathbf{- 1 3 . 5 2}$ & $\mathbf{- 1 7 . 0 0}$ \\
Vilnjus & & -0.76 & -0.05 & 2.90 & 7.64 & 6.45 & 0.35 & 2.46 \\
Odessa & & 0.02 & -0.36 & -0.56 & -0.46 & 0.28 & -0.29 \\
\hline
\end{tabular}

cally significant decrease was noted in February $(>10 \mathrm{~cm})$, March and April $(>25 \mathrm{~cm})$. At these 3 stations, mean winter snow cover depth changed significantly by $15 \mathrm{~cm}$ (Kirov, Orenburg) and by $10 \mathrm{~cm}$ (Gorkij). There was no significant trend at Vilnjus and Odessa, which have the smallest quantities of snow cover.

The trends in snow cover depth do not fully explain snow cover accumulation over the 20th century, and the Mann-Kendall test was applied to determine whether the trends were constant (see 'Data and methods').

At Kirov the most pronounced change in the trend occurred in 1950 (Fig. 2). After $40 \mathrm{yr}$ of decrease (1897-1937) fluctuations occurred in 1937-1950. Since 1950, however, the mean snow cover depth has increased again; trend equations are given in Fig. 3. The average decrease in the mean snow cover depth before 1950 was $4.0 \mathrm{~cm}$ per decade and the increase after 1950 was $3.9 \mathrm{~cm}$ per decade.

At Gorkij, the 1897-1908 period was characterised by a rapid increase in snow depth $(16.6 \mathrm{~cm}$ per decade); after the turning point in 1908 it decreased by $<1 \mathrm{~cm}$ per decade (Figs. 2 \& 3). At Vilnjus, the turning point was in 1982. Before this, a slow increase $(<1 \mathrm{~cm}$ per decade) was observed; in the 1980s snow depth decreased by $17 \mathrm{~cm}$ per decade. No turning points were found for Orenburg, as snow cover has constantly decreased throughout the 20th century. At Odessa, snow cover depth remained stable (data not shown).
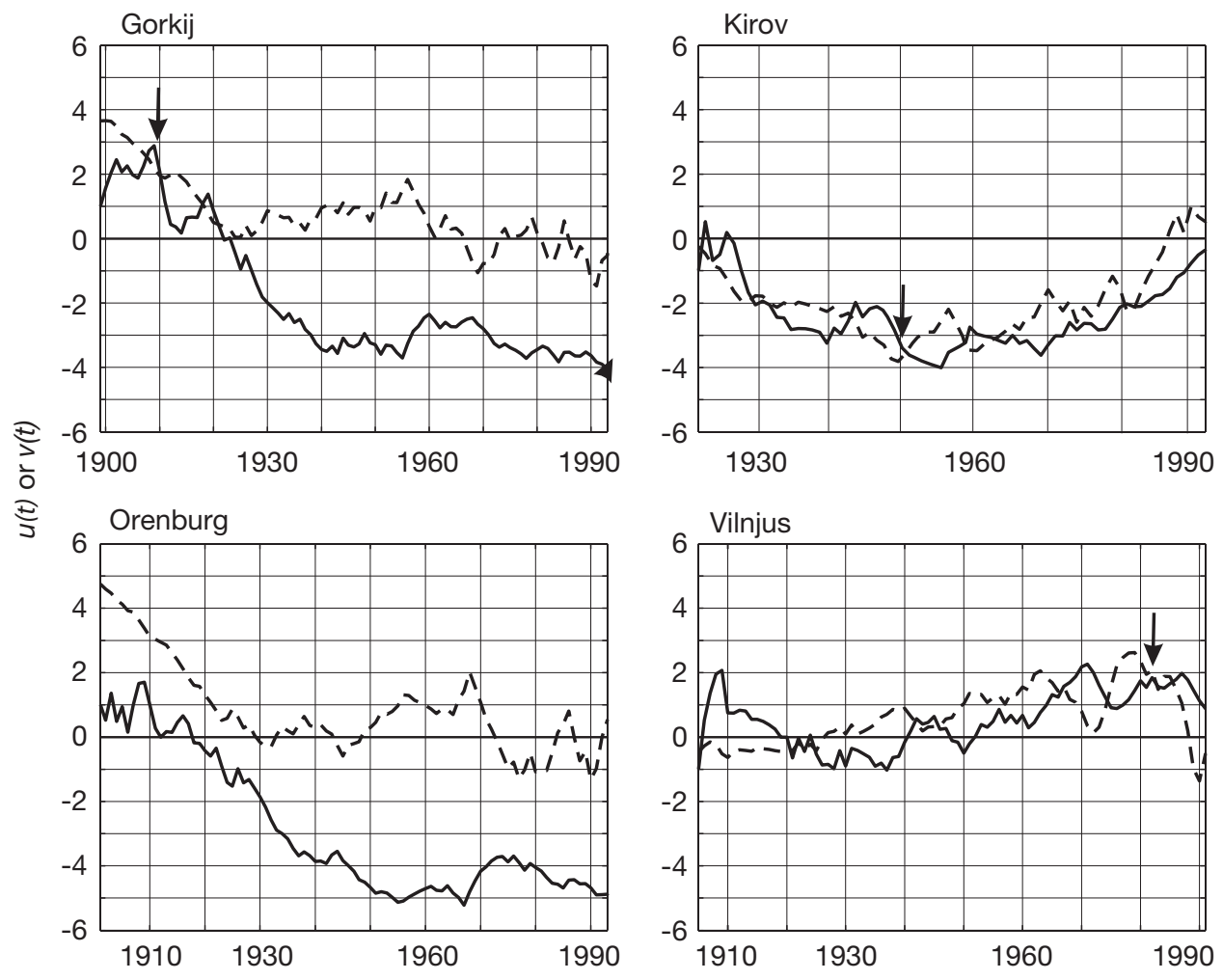

Fig. 2. Values of $u(t)$ (continuous lines) and $v(t)$ (dashed lines) of the sequential Mann-Kendall test. Arrows: turning points suggested by $u(t)$ and $v(t)$ lines crossing at maximum $|u(t)|$ and $|v(t)|$ values 

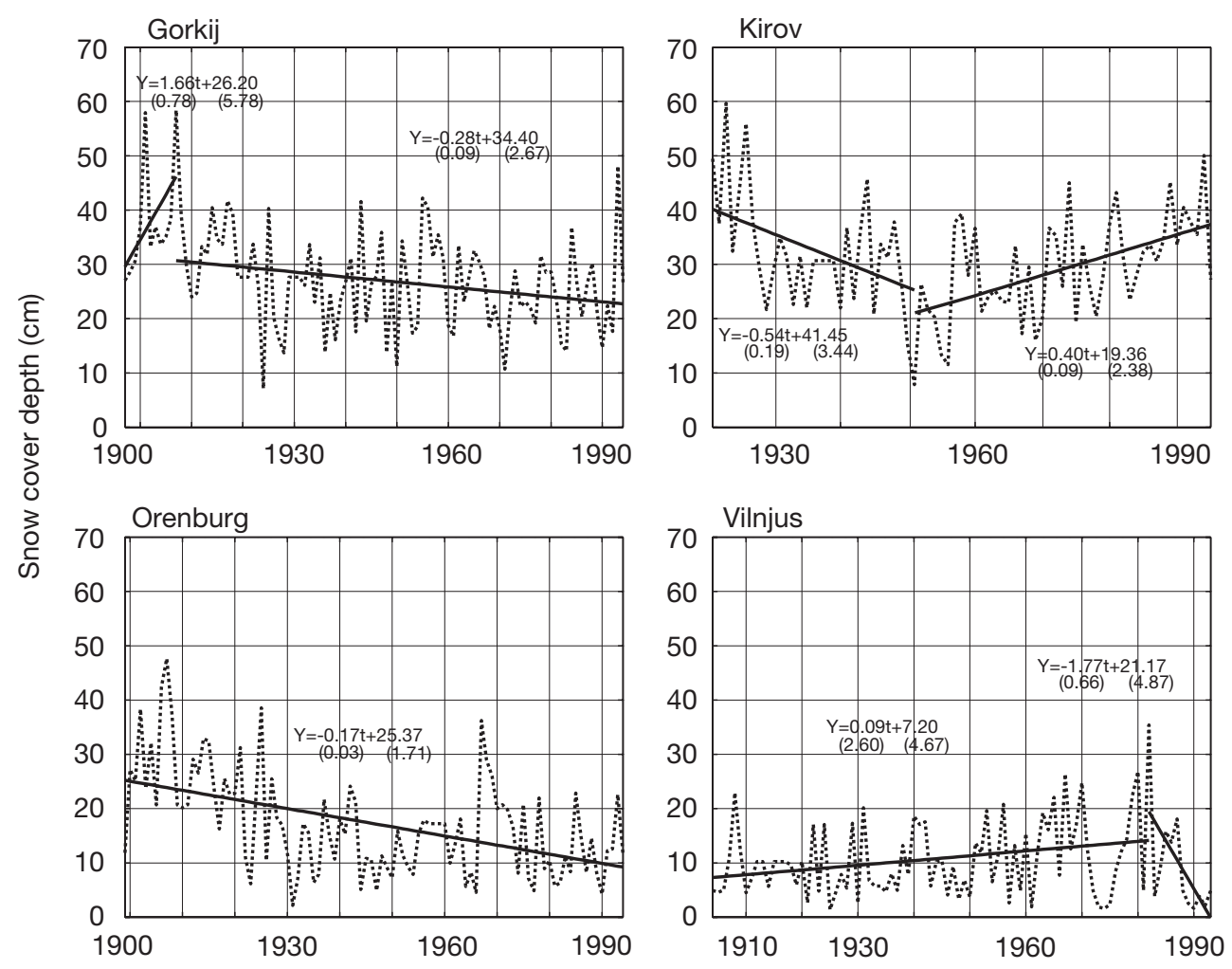

Fig. 3. Mean winter snow cover depth ( $\mathrm{cm}_{\text {; }}$ dashed lines) and linear trends of mean winter snow cover depth with equations

\section{DISCUSSION AND CONCLUSIONS}

Mean winter snow cover depth declined during the 20th century at most stations in eastern Europe. This confirms the results obtained by Ye et al. (1998), who observed a slight decrease in snow accumulation in European Russia over the period 1936-1983, by Jaagus (1997), who found a decrease in the number of days with snow cover in the 20th century in Estonia, and by Falarz (2002), who reported a strong decreasing tendency for snow cover characteristics in southern Poland during 1961-1990.

Changes in mean winter snow depth are related to changes in winter temperature and precipitation. An increase in winter air temperature has been observed in the mid-latitudes of European Russia (Chapman \& Walsh 1993, Kożuchowski \& Marciniak 1988). This means that the thermal winter (i.e. the season with daily mean temperature $<0^{\circ} \mathrm{C}$ ) is becoming shorter and the spring season starts earlier (Jaagus et al. 2003). This results in a decrease in the number of days with snow cover in those regions where temperature is the main factor determining snow cover.

The decrease in snow cover was not constant, as there were some rapid changes in trend. For example, at Kirov, where an overall negative trend was identi- fied for the entire period, there was a change in trend direction in 1950. Kirov is farthest to the northeast and has the the greatest quantity of snow among the 5 stations. The thermal winter lasts 130 to $150 \mathrm{~d}$ (Jaagus et al. 2003) and the mean temperature of the coldest month drops below $-18^{\circ} \mathrm{C}$. Consequently, winter precipitation most commonly consists of snow. The increase in precipitation in the 20th century observed at mid- and high latitudes in Europe (Kożuchowski \& Marciniak 1988, Vinnikov et al. 1990) increases winter snow accumulation in regions where winter temperature remains constantly well below $0^{\circ} \mathrm{C}$. This may explain the increase in snow cover depth at Kirov since 1950.

At Vilnjus, a change from a slight increase to a rapid decrease occurred in 1982. The same period is characterised by the largest decrease in the number of days with snow cover in Estonia (Jaagus 1997). In the 1980s and early 1990s high positive North Atlantic Oscillation (NAO) indices were noted (Hurrell 1995). The NAO influence on snow cover is weaker eastward and can affect snow cover depth up to the western border of Russia (Bednorz 2004). High positive NAO indices in the 1980s and early 1990s probably caused the rapid decrease in snow cover depth at Vilnjus during the last 2 decades of the 20th century. At Gorkij, a turning 
point from a positive to a negative tendency took place in 1908. A rapid decrease in snow cover extent (especially in the second half of the snow season) has also been noted in the northern hemisphere in the 1980s and early 1990s (Groisman et al. 1994). It may be a consequence of the warming observed globally since 1976 (IPCC 2001).

Snow cover occurrence is characterised by high diversity and variability from year to year. The range of mean winter snow depth is wide and the extreme values seem to have a strong impact on trends and turning points. At Gorkij and Vilnjus a year of maximum snow depth is a turning point from a positive to a negative trend in snow cover depth. At Kirov, a rapid change from a negative to a positive trend occurred in 1950, when the winter with the lowest quantity of snow occurred.

Acknowledgements. We thank the 4 anonymous reviewers for constructive comments. Special thanks to H. GórnickaHoleczek and A. Mularski for improving the English.

\section{LITERATURE CITED}

Alexanderson $\mathrm{H}$ (1986) A homogeneity test applied to precipitation data. J Clim 6:661-675

Armstrong R (2001) Historical Soviet Daily Snow Depth Version 2 (HSDSD). National Snow and Ice Data Center, Boulder, $\mathrm{CO}$

Bednorz E (2002) Snow cover in western Poland and macroscale circulation conditions. Int J Climatol 22:533-541

Bednorz E (2004) Snow cover in eastern Europe in relation to temperature, precipitation and circulation. Int J Climatol 24:591-601

Brown RD (2000) Northern Hemisphere snow cover variability and change, 1915-97. J Clim 13:2339-2355

Brown RD, Goodison BE (1996) Interannual variability in reconstructed Canadian snow cover 1915-1992. J Clim 9: 1299-1318

Brunetti M, Maugeri M, Nanni T (2001) Changes in total precipitation, rainy days and extreme events in northeastern Italy. Int J Climatol 21:861-871

Chapman WL, Walsh JE (1993) Recent variations of sea ice and air temperature in high latitudes. Bull Am Meteorol Soc 74:33-47

Cohen J (2001) The influence of snow cover on Northern Hemisphere climate variability. Atmos Ocean 39(1):35-53

Dewey KF (1977) Daily maximum and minimum temperature forecasts and the influence of snow cover. Mon Weather Rev 105:1594-1597

Falarz M (2002) Long-term variability in reconstructed and observed snow cover over the last 100 winter seasons in Cracow and Zakopane (southern Poland). Clim Res 19: 247-256

Gerstengarbe FW, Werner PC (1999) Estimation of the beginning and end of recurrenent events within a climate regime. Clim Res 11:97-107

Groisman PY, Karl TR, Knight RW, Stenchikov GL (1994) Changes of snow cover, temperature and the radiative heat balance over the Northern Hemisphere. J Clim 7: 1633-1656

Gutzler DS, Rosen RD (1992) Interannual variability of wintertime snow cover across the Northern Hemisphere. J Clim 5:1441-1447

Hughes MG, Robinson DA (1996) Historical snow cover variability in the Great Plains region of the USA: 1910 through to 1993. Int J Climatol 16:1005-1018

Hurrell JW (1995) Decadal trends in the North Atlantic Oscillation: regional temperatures and precipitation. Science 269:676-679.

IPCC (2001) Climate change 2001: synthesis report. A contribution of working groups I, II and III to the third assessment report of the Intergovernmental Panel of Climate Change. Cambridge University Press, Cambridge

Jaagus J (1997) The impact of climate change on the snow cover pattern in Estonia. Clim Change 36:65-77

Jaagus J, Truu J, Ahas R, Aasa A (2003) Spatial and temporal variability of climatic seasons on the East European Plain in relation to large scale atmospheric circulation. Clim Res 23:111-129

Johnson RH, Young GS, Toth JJ, Zehr RM (1984) Mesoscale weather effects of variable snow cover over Northeast Colorado. Mon Weather Rev 112:1141-1152

Karl TR, Groisman PY, Knight RW, Heim RR (1993) Recent variations of snow cover and snowfall in North America and their relation to precipitation and temperature variations. J Clim 6:1327-1344

Kożuchowski K, Marciniak K (1988) Variability of mean monthly temperatures and semi-annual precipitation totals in Europe in relation to hemispheric circulation patterns. Int J Climatol 8:191-199

Namias J (1985) Some empirical evidence for the influence of snow cover on temperature and precipitation. Mon Weather Rev 113:1542-1553

Robinson DA (1993) Historical daily climatic data for the United States. 8th Conf Appl Climatol, Anaheim, CA, 17-23 Jan, 1993. American Meteorological Society, p 264-269

Robinson DA, Kukla G (1985) Maximum surface albedo of seasonally snow-covered lands in the Northern Hemisphere. J Clim Appl Meteorol 24:402-411

Robock A (1980) The seasonal cycle of snow cover, sea ice and surface albedo. Mon Weather Rev 108:267-285

Sneyers R (1990) On the statistical analysis of series of observation. Tech Note No. 143, World Meteorological Organisation, Geneva

Vinnikov KY, Groisman PY, Lugina KM (1990) Empirical data on contemporary global climate changes (temperature and precipitation). J Clim 3:662-677

Wagner AJ (1973) The influence of average snow depth on monthly mean temperature anomaly. Mon Weather Rev 101:624-626

Walsh JE, Tucek DR, Peterson MR (1982) Seasonal snow cover and short-term climatic fluctuations over the United States. Mon Weather Rev 110:1474-1485

Wibig J (2001) Wpływ cyrkulacji atmosferycznej na rozkład przestrzenny anomalii temperatury i opadów w Europie. Wydawnictwo Uniwersytetu Łódzkiego, Łódź

Ye H (2000) Decadal variability of Russian winter snow accumulation and its associations with Atlantic sea surface temperature anomalies. Int J Climatol 20:1709-1728

Ye H, Cho HR, Gustafson PE (1998) The changes in Russian winter snow accumulation during 1936-83 and its spatial patterns. J Clim 11:856-863

Submitted: April 2, 2004; Accepted: October 6, 2004

Proofs received from author(s): October 27, 2004 